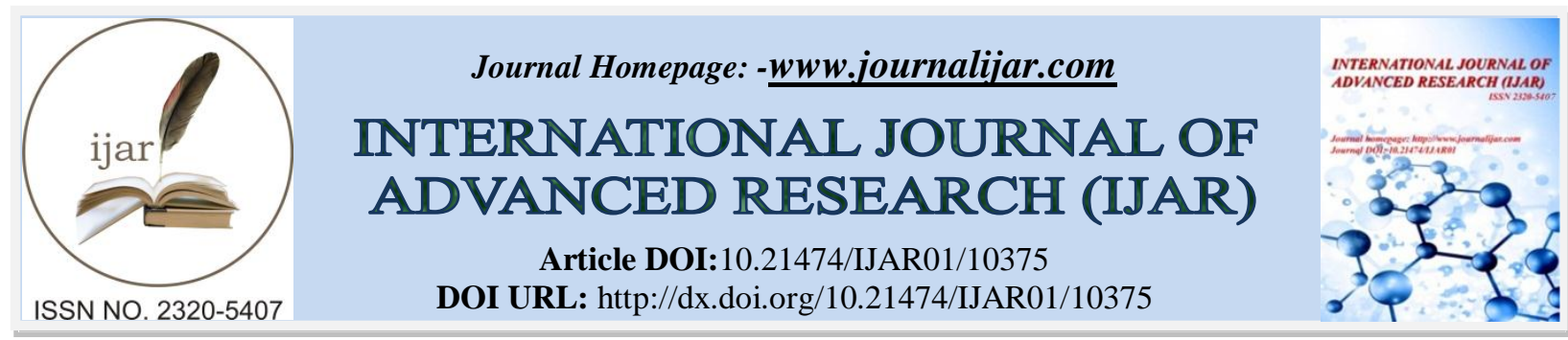

RESEARCH ARTICLE

\title{
MICROSTRUCTURAL AND MECHANICAL PROPERTIES OF MODIFICATED PRECIPITATION HARDENING STEEL 17-7PH AFTER MODIFICATION HEAT TREATMENT
}

\author{
B. Fakić ${ }^{1}$, Adisa Burić ${ }^{1}$ and Diana Ćubela ${ }^{2}$ \\ 1. University of Zenica, Institute "Kemal Kapetanović" of Zenica. \\ 2. University of Zenica, Faculty of Metallurgy and Technology.
}

\section{Manuscript Info}

….......................

Manuscript History

Received: 30 November 2019

Final Accepted: 31 December 2019

Published: January 2020

Key words:-

Modification, Steel 17-7PH, Elevated

Temperature, Mechanical Properties,

Microstructure, Regression Analysis,

Precipitation Hardening

\section{Abstract}

Precipitation hardening stainless steel 17-7PH with modified chemical composition was heat treated by modified RH950 condition. In this paper is presented the results of tests of microstructure and mechanical properties of precipitation hardened stainless steel 17-7PH with modified chemical composition, heat treated in modificated RH950 conditions. Regression analysis showed which variables are statistically significant in predicting the value of mechanical properties of the steel 17-7PH chemically modified composition.

Copy Right, IJAR, 2020,. All rights reserved.

\section{Introduction:-}

Precipitated hardening $(\mathrm{PH})$ Stainless Steels are iron-chromium-nickel alloys by the addition of one or more precipitating hardening elements such as aluminum, titanium, copper, niobium and molybdenum. Mechanical properties, such as tensile strength $R_{m}$, yield strength $R_{0,2}$ and elongation $A$ at elevated temperature give a lot of information about the material. Testing of the mechanical properties at elevated temperature of the samples was carried out in 16 melts, made in accordance with the design of the experiment. Regression analysis showed which variables were statistically significant for predicting value of $R_{m}, R_{0,2}$ and $A$ in steel 17-7PH with modified chemical composition.

\section{Precipitation Hardening Stainless Steel:}

Today, there are over 60 standardized and over 100 non-standardized chemical compositions stainless steel. Stainless steel is divided according to their microstructure into five groups [1,2]:

1. austenitic,

2. martensite,

3. ferrite,

4. austenitic-ferrite (duplex),

5. precipitated hardening.

Precipitation hardened stainless steels are chromium and nickel containing steels that can hold high value of strength at elevated temperatures. One of the most common grade is $17-7 \mathrm{PH}$, with the composition of $17 \%$ chromium, $7 \%$ nickel and about $1 \%$ aluminum.

The advantage of this steel is their possibility to be machined in softer solution treated condition (solution annealing), and following machining or forming can be hardened by ageing heat treatment which causes low or no distorsion of the component [4]. 
Precipitation hardened stainless steel possess good corrosion resistance and excellent mechanical properties. Depending of the austenite stability precipitation-hardened stainless steels can be classified into classes [2,3,5,6,7]:

1. Austenitic,

2. Semi-austenitic

3. Martensitic steels.

Precipitation hardening is generally achieved from homogeneously nucleated fine precipitates of intermetallic phases [8].

\section{Semi-austenitic PH steels:}

Precipitation takes place from the indirectly obtained martensite. These steels are austenitic in the solution annealed condition. They may contain from 5 to $20 \%$ of delta ferrite $[2,6,9]$. Semi-austenitic steels are ductile in a solution annealed condition and are easy to machined. The content of elements that extend alpha and gamma regions must be carefully balanced to obtain the desired properties of these steels. Cooling from solution annealing temperature must be fast enough to avoid grain coarsening [2,6].

The position of PH steel in the Schaeffler-Delong diagram is given in Figure $1[2,7,10]$.

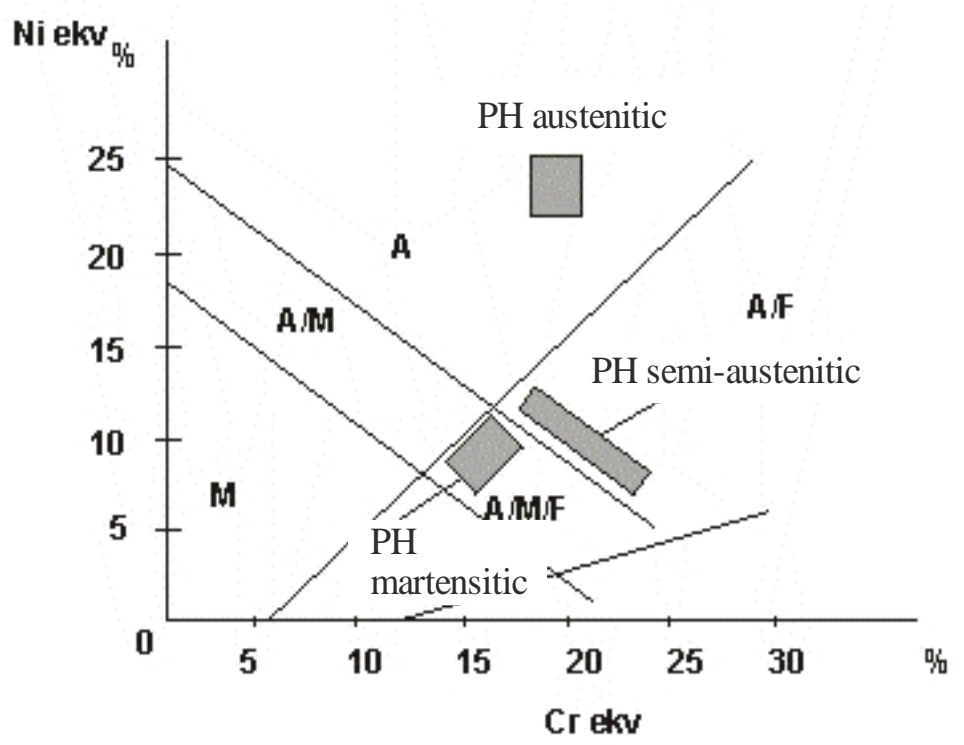

Figure 1: Location PH steels in Schaeffler-Delong diagramu [2,7].

\section{Information Of Testing Material:}

Chemical Composition:

Chemical composition of testing material and standard chemical composition for 17-7PH steel is given bellow.

Table 1:- Standard chemical composition of 17-7PH steel.

\begin{tabular}{|l|l|l|l|l|l|l|l|l|}
\hline \multirow{2}{*}{ Standard } & \multicolumn{6}{|l|}{ Chemical composition, [mas \%] } \\
\cline { 2 - 9 } & $\mathrm{C}, \max$ & $\mathrm{Mn}, \mathrm{Max}$ & $\mathrm{Si}, \max$ & $\mathrm{P}, \max$ & $\mathrm{S}, \max$ & $\mathrm{Cr}$ & $\mathrm{Ni}$ & $\mathrm{Al}$ \\
\hline BAS EN 10088-5 [10] & 0,09 & 1,0 & 0,7 & 0,040 & 0,015 & $16,0-18,0$ & $6,5-7,8$ & $0,7-1,5$ \\
\hline ASTM A564/A564M [11] & 0,09 & 1,0 & 1,0 & 0,040 & 0,030 & $16,0-18,0$ & $6,5-7,75$ & $0,75-1,5$ \\
\hline
\end{tabular}

Modification of chemical composition for tested batches compared with the required chemical composition of 177PH steel is reflected in the content of chromium, nickel and aluminum, while the content of the five basic elements $(\mathrm{C}, \mathrm{Si}, \mathrm{Mn}, \mathrm{P}$ and $\mathrm{S}$ ) is within the limits prescribed in Table 1, and modification of chemical composition is ranged from 13.8 to $15.7 \%$ for chromium, for nickel from 7.3 to $9.1 \%$, while aluminum content was from 0.61 to $1.53 \%$ [2]. 


\section{Making experimental samples:}

For the purposes of the experiment, sixteen experimental melts were made, with an ingot weight of 6 to $8 \mathrm{~kg}$. The melts were produced in semi-industrial plant, in a vacuum induction furnace. Plastic processing of forging and rolling processed at semi-industrial plants. Forging was performed on 200 t hydraulic press and air hammer B250 with several warm-ups. Forging is completed after reaching a dimension of $\phi 18 \mathrm{~mm}$. Hot rolling up to a final dimension of $\phi 16 \mathrm{~mm}$ was carried out on a semi-industrial line SKET rolling mill, with a roller diameter of $\phi 350$ $\mathrm{mm}$ at a temperature interval of 1150 to $950{ }^{\circ} \mathrm{C}$ [2].

\section{Modificated heat treatment RH950:}

Rolled bars diameter $16 \mathrm{~mm}$ are heat treated solution annealing in a furnace without a protective atmosphere: heating to a temperature of $1050^{\circ} \mathrm{C}$ for 115 minutes, holding at $1050^{\circ} \mathrm{C}$ for 30 minutes and cooled in air. A diagram of the solution annealing is given in Figure 2.

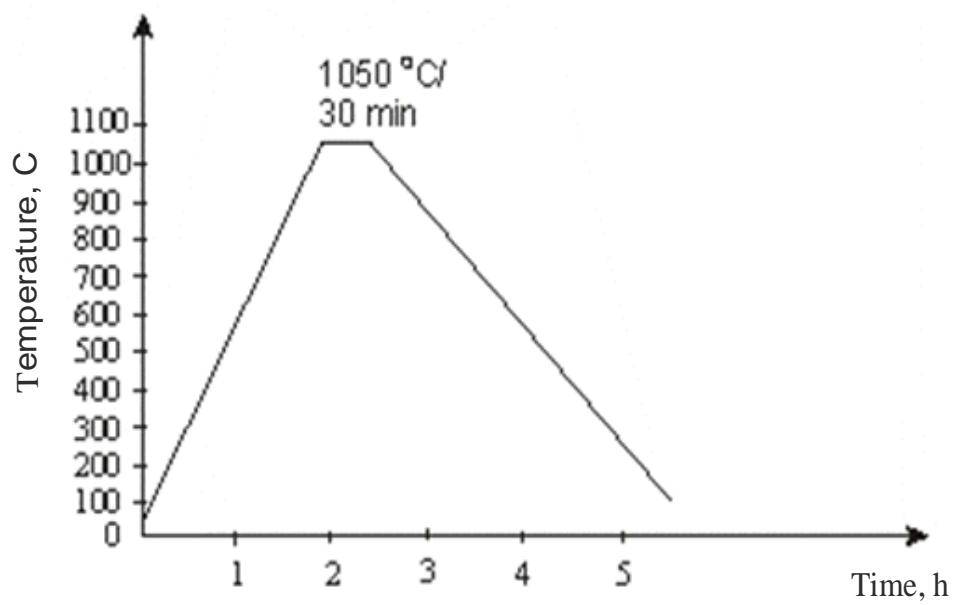

Figure 2: Diagram of solution annealing for steel with modified chemical composition 17-7PH

The high strength of precipitation hardened 17-7PH stainless steel is achieved in the following steps:

1. conditioning of austenite: heating up to $955^{\circ} \mathrm{C}$ for 90 minutes, holding at this temperature 10 minutes,

2. cooling below a critical temperature to transform austenite into martensite: cooling to air at room temperature, cooling to $-50^{\circ} \mathrm{C}$ in dry ice within one hour and holding for 8 hours and heating to room temperature,

3. precipitation hardening: heating to $510^{\circ} \mathrm{C}$ for 45 minutes and holding at that 60 minutes and air cooling.

Diagrams of the heat treatment are given in Figure 3.

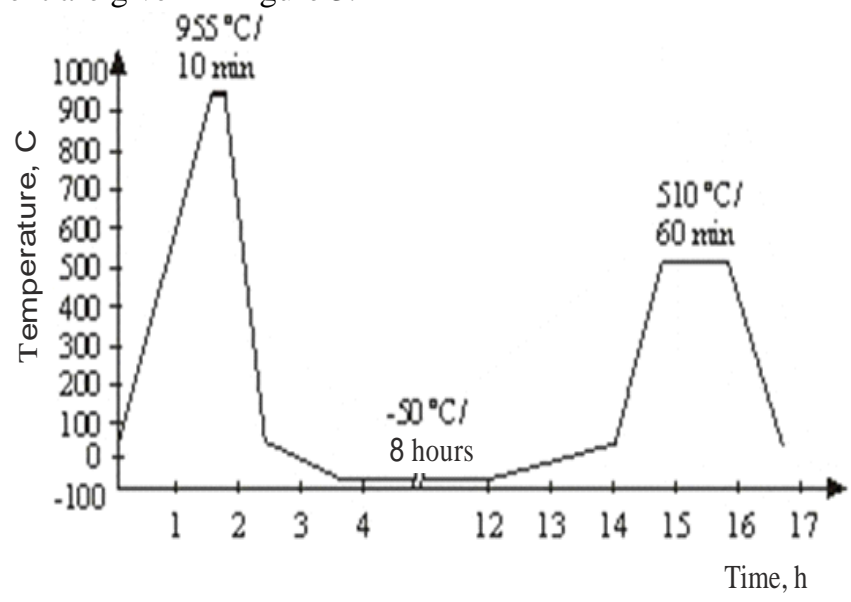

Figure 3: Diagram of precipitation annealing for steel with modified chemical composition 17-7PH 
Testing Of Mechanical Properties In The Modified RH950 Condition:

The literature values of mechanical properties for 17-7PH stainless steel in condition RH950 and results of testing mechanical properties at elevated temperature for steel 17-7PH with modification chemical composition in modified RH950 condition are given in Table 2.

Table 2:- Test results of mechanical properties in modified condition RH950 at elevated temperature [2].

\begin{tabular}{|l|l|l|l|}
\hline \multirow{2}{*}{ Literature / } & $\mathrm{R}_{\mathrm{m}}\left[\mathrm{N} / \mathrm{mm}^{2}\right]$ & $\mathrm{Rp}_{0,2}\left[\mathrm{~N} / \mathrm{mm}^{2}\right]$ & $\mathrm{A}[\%]$ \\
\cline { 2 - 4 } & $425{ }^{\circ} \mathrm{C}$ & $425{ }^{\circ} \mathrm{C}$ & $425{ }^{\circ} \mathrm{C}$ \\
\hline Metals handbook [1] & - & - & - \\
Stainless steel [13] & 1100 & 895 & - \\
AK Steel bulletin [14] & 1103 & 945 & 12 \\
\hline V1781 & 1030 & 950 & 11,5 \\
\hline V1782 & 1036 & 974 & 13,5 \\
\hline V1772 & 1060 & 968 & 11,5 \\
\hline V1773 & 1020 & 1010 & 12,0 \\
\hline V1749 & 959 & 897 & 8,0 \\
\hline V1754 & 1011 & 962 & 11,0 \\
\hline V1774 & 1126 & 1039 & 15,5 \\
\hline V1775 & 1082 & 1040 & 10,5 \\
\hline V1747 & 967 & 934 & 10,5 \\
\hline V1755 & 1007 & 962 & 10,0 \\
\hline V1760 & 913 & 891 & 16,5 \\
\hline V1783 & 1100 & 1068 & 12,5 \\
\hline V1752 & 1004 & 984 & 13,5 \\
\hline V1753 & 1003 & 921 & 14,5 \\
\hline V1750 & 1066 & 974 & 9,5 \\
\hline V1756 & 1056 & 1032 & 14,0 \\
\hline
\end{tabular}

A diagrammatic overview of the results of testing mechanical properties at elevated temperature is given in Figure 4.
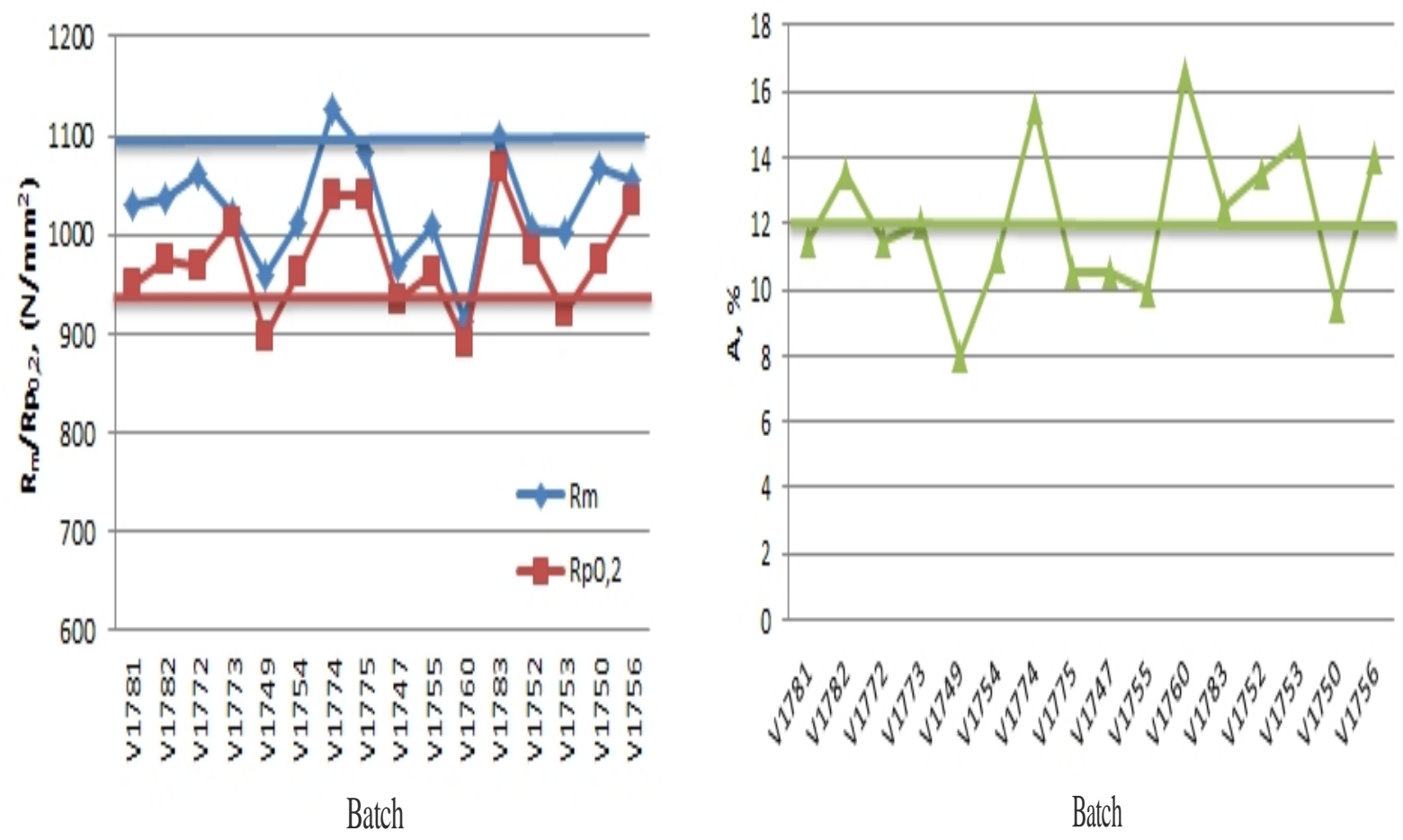

Figure 4: Diagram of results of testing mechanical properties at elevated temperature. 


\section{Mikrostructure Testing In The Modified RH950 Condition:}

Metallographic analysis of samples in the modified RH950 condition revealed the microstructure of martensite and austenite and the presence of a small amount of delta ferrite. The appearance of the microstructure of specimens in the modified RH950 condition for batch V1760 and batch V1774 is given in Figures 5 and 6.

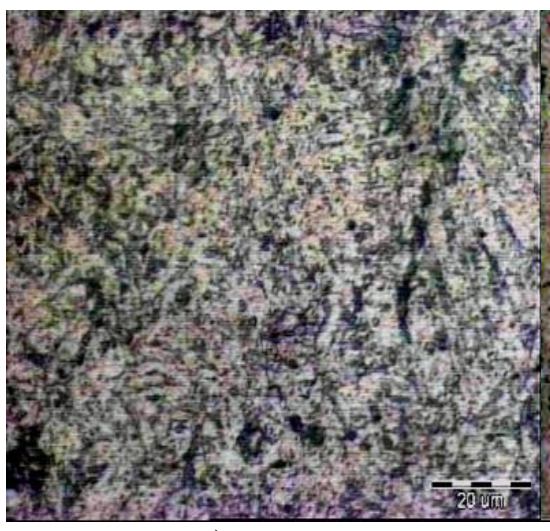

a)

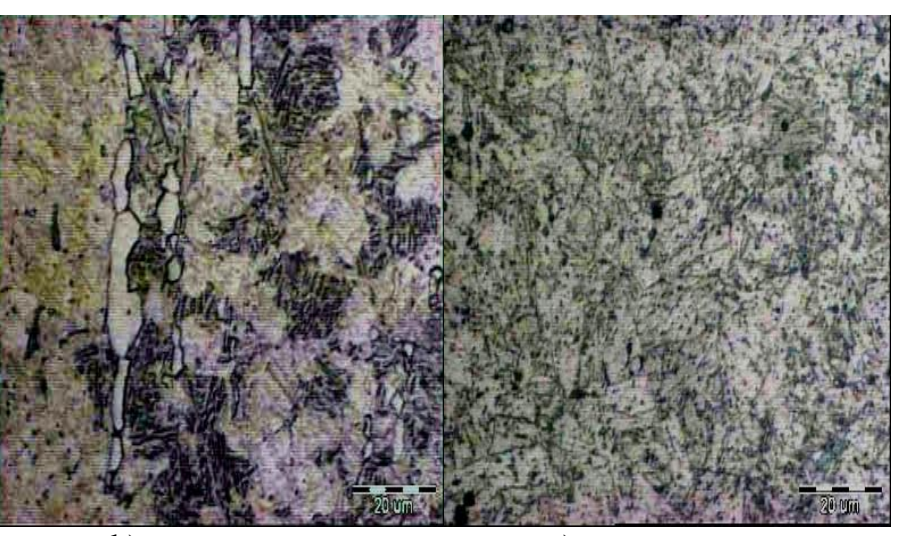

b) c)

Figure 5:- Batch V1760, hardness 526HV10, a) and b) longitudinal to the rolling direction; c) transversely to the rolling direction, Kalling reagent, present $83,4 \%$ of martensite and delta ferrite and $16,6 \%$ of austenite

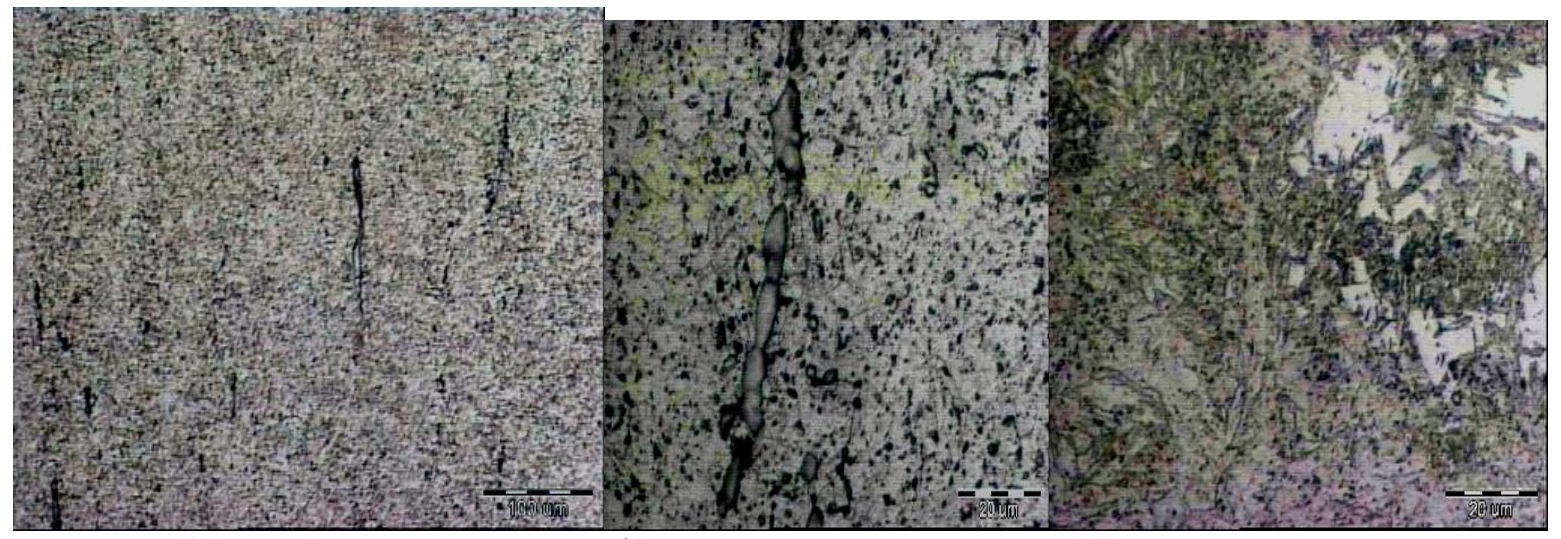

a)

b)

c)

Figure 6: Batch V1774; hardness 535 HV10, a) and b) longitudinal to the rolling direction; c) transversely to the rolling direction, Kalling reagent, present $85,5 \%$ of martensite and delta ferrite and $14,5 \%$ of austenite

As microstructure show there are achieved the good percent of martensite, more than 80 percent and less than $5 \%$ of delta ferrite.

Regression Analysis Of The Effect Of Chromium, Nickel And Aluminum Content For The RH950 Condition: Regression analysis of the results obtained by testing the mechanical properties after precipitation annealing at elevated temperature (Table 2), determined the correlation between the chromium, nickel, aluminum content and their interactions with independently variables $-R_{m}, R_{0,2}$ and $A$.

The values of the correlation coefficients and the interrelation of independently variable chromium, nickel and aluminum, and their interactions for the modified RH950 condition are given in Table 3.

Table 3:- Correlation coefficients for the modified RH950 condition at elevated temperature.

\begin{tabular}{|l|l|l|l|l|l|l|l|l|}
\hline & $\mathrm{Cr}$ & $\mathrm{Ni}$ & $\mathrm{Al}$ & $\mathrm{CrNi}$ & $\mathrm{CrAl}$ & $\mathrm{NiAl}$ & $\mathrm{CrNiAl}$ & $\mathrm{R}_{\mathrm{m}} / \mathrm{Rp}_{0,2} / \mathrm{A}$ \\
\hline $\mathrm{R}_{\mathrm{m}}$ & 0,063 & $-0,344$ & 0,396 & $-0,337$ & 0,4022 & 0,2902 & 0,3023 & 1 \\
\hline $\begin{array}{l}\text { Index } \\
\text { variable }\end{array}$ & $\mathrm{x} 7$ & $\mathrm{x} 3$ & $\mathrm{x} 2$ & $\mathrm{x} 4$ & $\mathrm{x} 1$ & $\mathrm{x} 6$ & $\mathrm{x} 5$ & --- \\
\hline $\mathrm{Rp}_{0,2}$ & 0,2625 & $-0,383$ & 0,371 & $-0,267$ & 0,4173 & 0,2467 & 0,2957 & 1 \\
\hline
\end{tabular}




\begin{tabular}{|l|l|l|l|l|l|l|l|l|}
\hline $\begin{array}{l}\text { Index } \\
\text { variable }\end{array}$ & $\mathrm{x} 6$ & $\mathrm{x} 2$ & $\mathrm{x} 3$ & $\mathrm{x} 5$ & $\mathrm{x} 1$ & $\mathrm{x} 7$ & $\mathrm{x} 4$ & -- \\
\hline A & 0,0817 & $-0,379$ & 0,536 & $-0,373$ & 0,5598 & 0,4080 & 0,4359 & 1 \\
\hline $\begin{array}{l}\text { Index } \\
\text { variable }\end{array}$ & $\mathrm{x} 7$ & $\mathrm{x} 5$ & $\mathrm{x} 2$ & $\mathrm{x} 6$ & $\mathrm{x} 1$ & $\mathrm{x} 4$ & $\mathrm{x} 3$ & --- \\
\hline
\end{tabular}

Based on the results of the regression analysis, the following regression models were selected for the modified RH950 condition:

At elevated temperature:

$R_{m}=-201,68 \mathrm{CrAl}+2624,38 \mathrm{Al}+6,77 \mathrm{Ni}-6,38 \mathrm{CrNi}+20,85 \mathrm{CrNiAl}-$

$247,21 \mathrm{NiAl}+108,481 \mathrm{Cr}$

$R p_{0,2}=148,94 C r A l+114,75 N i-2073,41 A l-12,48 C r N i A l-9,82 C r N i+$

$74,32 \mathrm{Cr}+184,59 \mathrm{NiAl}$

$A=14,52 \mathrm{CrAl}-236,23 \mathrm{Al}-1,71 \mathrm{CrNiAl}+28,59 \mathrm{NiAl}+2,89 \mathrm{Ni}-0,55 \mathrm{CrNi}+3,297 \mathrm{Cr}$

The results of the regression analysis, the diagrams of the measured and predicted values, the diagrams of standardized residuals versus percentiles, and the diagrams of the standardized residuals versus regression schedules are given at figure 7 to 9 .

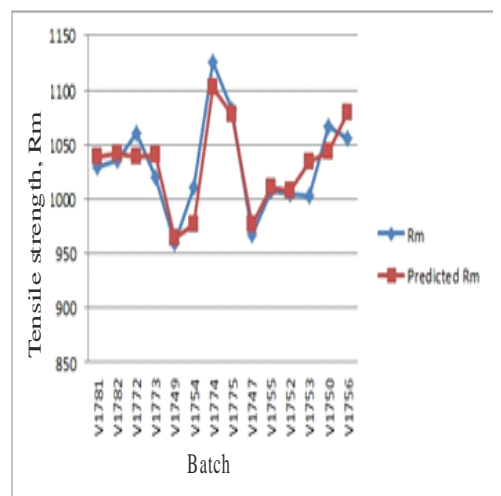

a)

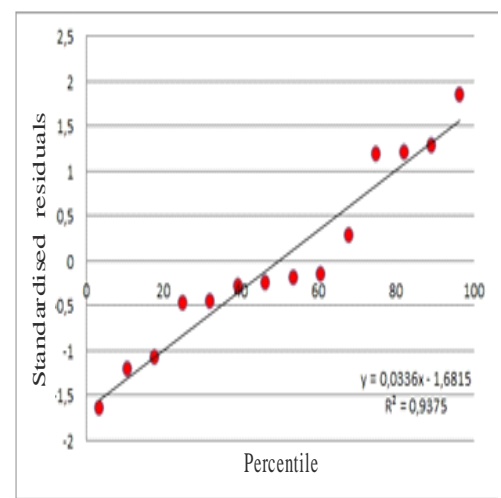

b)

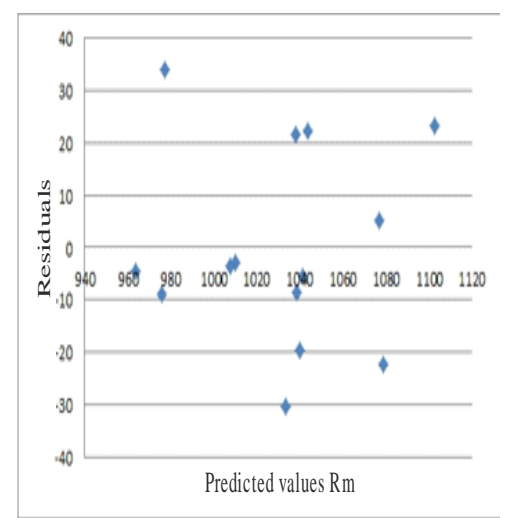

c)

Figure 7:- Diagrams for tensile strength, $\mathrm{R}_{\mathrm{m}}$

a) of measured and predicted values b) of standardized residuals versus percentiles c) of residuals versus regression

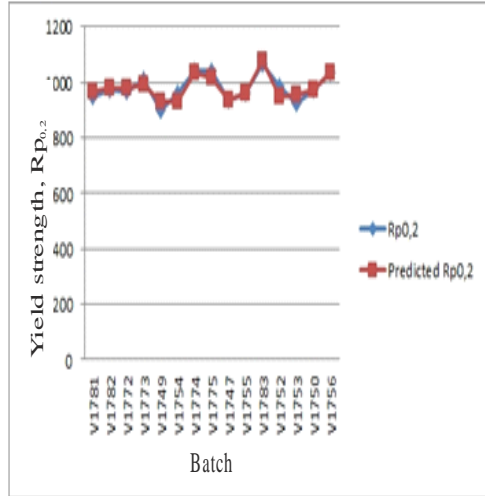

a)

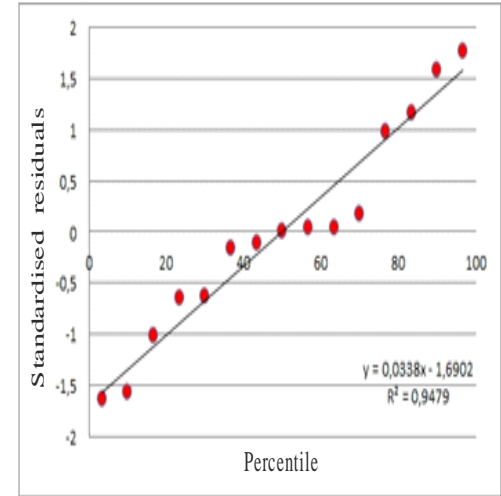

b)

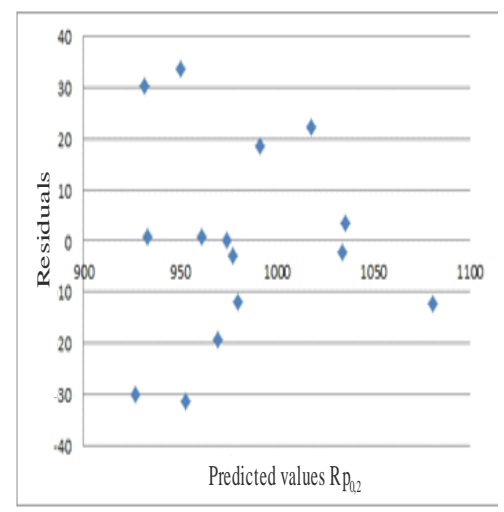

c)

Figure 8: Diagrams for yield strength, $\mathrm{Rp}_{0,2}$, a) of measured and predicted values $\mathrm{b}$ ) of standardized residuals versus percentiles c) of residuals versus regression 


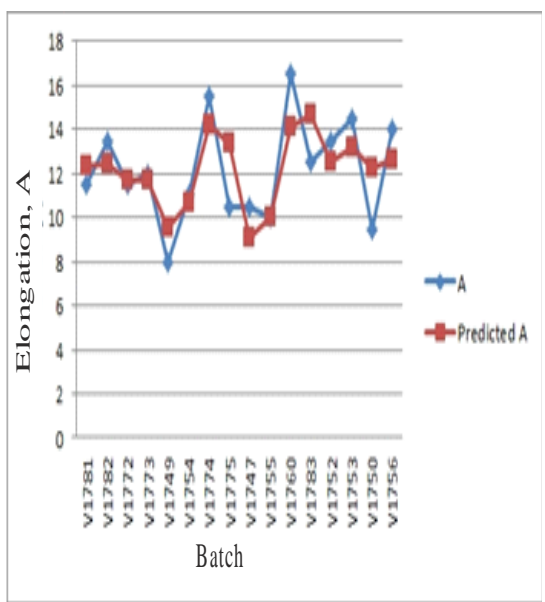

a)

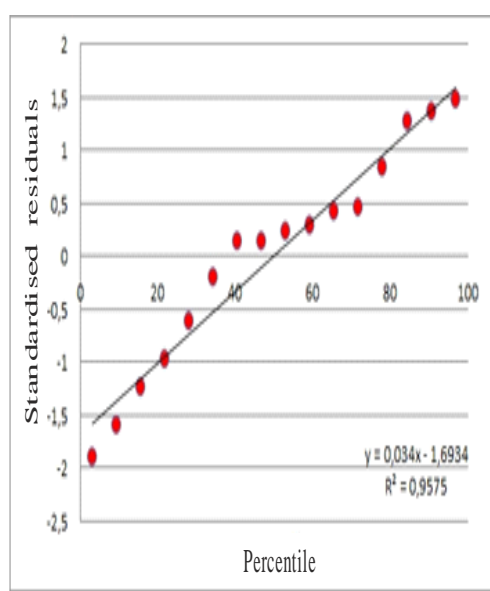

b)

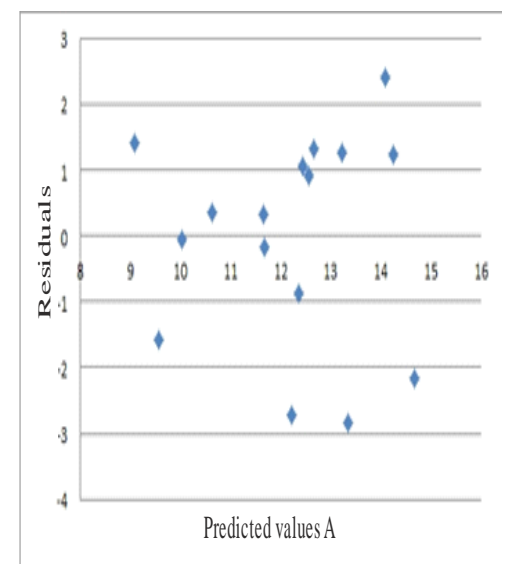

c)

Figure 9:- Diagrams for elongation, A, a) of measured and predicted values b) of standardized residuals versus percentiles c) of residuals versus regression.

\section{Conclusion:-}

Testing of the mechanical properties at an elevated temperature of $425^{\circ} \mathrm{C}$, for the modified condition $\mathrm{RH} 950$ showed tensile strength values in the range of 913 to $1126 \mathrm{~N} / \mathrm{mm}^{2}, \mathrm{Rp}_{0,2}$ from 891 to $1068 \mathrm{~N} / \mathrm{mm}^{2}$. Elongation test results range from 8 to $16,5 \%$. Comparing the results with the values given in the literature for the prescribed chemical composition of 17-7PH steel in the precipitated hardening condition RH950 [14], it is evident that the modified chemical composition of $17-7 \mathrm{PH}$ steel can achieve the values of $\mathrm{R}_{\mathrm{m}}, \mathrm{Rp}_{0,2}$, A and hardness HV10 above literary.

Based on the values of the coefficients in the regression models (1) to (3) in the RH950 condition at an elevated temperature of $425^{\circ} \mathrm{C}$, it is observed that:

1. chromium, nickel, aluminum and the $\mathrm{CrNiAl}$ interaction have a positive effect, while the $\mathrm{CrNi}, \mathrm{CrAl}$ and $\mathrm{NiAl}$ interactions have a negative effect on the tensile strength;

2. chromium, nickel and the $\mathrm{CrAl}$ and $\mathrm{NiAl}$ interactions have a positive effect, while aluminum and the $\mathrm{CrNiAl}$ and $\mathrm{CrNi}$ interactions have a negative effect on the conventional yield strength;

3. chromium, nickel and $\mathrm{CrAl}$ and $\mathrm{NiAl}$ interactions have a positive effect, while aluminum and $\mathrm{CrNi}$ and $\mathrm{CrNiAl}$ interactions have a negative effect on elongation.

Based on the Student's t-test values, it can be concluded that a statistically significant influence on the tensile strength $\mathrm{R}_{\mathrm{m}}$ in the modified RH950 condition at the test at elevated temperature shows the Cr content, while no chemical element or a combination thereof individually shows a statistically significant influence on the values $\mathrm{Rp}_{0,2}$ and $\mathrm{A}$, but all combined, over the observed chemical composition interval, have a statistically significant influence (the value of $\mathrm{p}$ and $\mathrm{F}$ for the model in the analysis of variance).

\section{Literature:-}

1. Metals handbook: Properties and Selection: Iron, Steels and High-Performance, 10th Edition, Vol.1, ASM American Society for Metals, 1990.

2. Belma Fakić: A Modification of Chromium, Nickel and Aluminum Content in Precipitation Hardening Steel 17-7PH Intended for the Production of Automotive Engine Components, PhD, University of Zenica, December 2015

3. The Atlas Specialty Metals Technical Handbook of Stainless Steels http://www.pms-c.com/wp-content/uploads/2010/07/Atlas-Technical-Handbook-of-St-Steel-05-2008.pdf, available May 2012.

4. http://www.suppliersonline.com/propertypages/17-7.asp, available July 2013.

5. http://www.calphad.com/precipitation_hardening_stainless_steel.html, available June 2012.

6. Joseph $\mathrm{Ki}$ Leuk Lai at all: Stainless Steels: An Introduction and Their Recent Developments, http://books.google.ba, available July 2012. 
7. http://www.tech.plym.ac.uk/sme/interactive_resources/tutorials/failureanalysis/Undercarriage_Leg/Steel_Metall urgy_Ohio-State.pdf, available June 2012.

8. https://www.academia.edu/10902991/Chapter_2_Materials?email_work_card=view-paper, available January 2020.

9. Mladen Novosel, Dragomir Krumes: Posebni čelici, Slavonski Brod, 1998.

10. http://www.nhml.com/martensite-in-austenitic-stainless-steel-welds.cfm, available december 2012.

11. Standard EN 10088-3:2007 -Stainless steels - Part 3: Technical delivery conditions for semi- finished products, bars, rods, wire, sections and bright products of corrosion resisting steels for general purposes

12. Standard ASTM A564 / A564M Standard Specification for Hot-Rolled and Cold-Finished Age-Hardening Stainless Steel Bars and Shapes

13. R.A.Lula: Stainless steel, American Society for Metals, Ohio, 1985.

14. http://www.aksteel.com/pdf/markets_products/stainless/precipitation/17-7phdatabulletin.pdf, available January 2013. 